This item was submitted to Loughborough's Research Repository by the author.

Items in Figshare are protected by copyright, with all rights reserved, unless otherwise indicated.

\title{
Non-traditional business models for city-scale energy storage: evidence from UK case studies
}

PLEASE CITE THE PUBLISHED VERSION

https://doi.org/10.1007/s40812-017-0083-8

\section{PUBLISHER}

(C) Associazione Amici di Economia e Politica Industriale. Published by Springer

\section{VERSION}

AM (Accepted Manuscript)

\section{PUBLISHER STATEMENT}

This work is made available according to the conditions of the Creative Commons Attribution-NonCommercialNoDerivatives 4.0 International (CC BY-NC-ND 4.0) licence. Full details of this licence are available at: https://creativecommons.org/licenses/by-nc-nd/4.0/

\section{LICENCE}

CC BY-NC-ND 4.0

\section{REPOSITORY RECORD}

Burlinson, Andrew, and Monica Giulietti. 2019. "Non-traditional Business Models for City-scale Energy Storage: Evidence from UK Case Studies”. figshare. https://hdl.handle.net/2134/27369. 


\title{
Non-traditional business models for city-scale energy storage: evidence from UK case studies
}

\author{
Andrew Burlinson* and Monica Giulietti** \\ School of Business and Economics, University of Loughborough, Loughborough, UK
}

\begin{abstract}
This paper investigates emerging non-traditional business models for decentralised energy systems with a focus on the role of city-scale storage technologies. We discuss the key characteristics of the different business models which have been identified in the literature and we discuss case studies across the United Kingdom in order to illustrate the key factors which influence their adoption and implementation. On the basis of evidence from recent UK case studies we investigate the market and regulatory barriers, contractual and transactional issues which may prevent key actors from exploiting the full market potential of their assets. We find that emerging business models rely on a range of different revenue sources with some limitations due to complex contractual relations, regulatory barriers and limited access to markets for ancillary services. The evidence we provide can be used by companies and organisations intending to operate in this fast developing market and inform policymakers aiming to promote the expansion and improvement of emerging business models.
\end{abstract}

JEL codes: L21, L53, L94, D23

Keywords: Technology adoption, energy industry, business models, storage

Acknowledgements: The authors acknowledge financial support from the EPSRC (grants EP/N001745/1 and EPR062258/1). Monica Giulietti also receives EPSRC funding (grant $\mathrm{EP} / \mathrm{K} 002228)$.

\footnotetext{
* Post-doctoral fellow, School of Business and Economics, University of Loughborough, Loughborough, UK, A.C.Burlisonson@1boro.ac.uk

** Corresponding author: Professor of Microeconomics, School of Business and Economics, University of Loughborough, Loughborough, UK, M.Giulietti@1boro.ac.uk
} 


\section{Introduction}

"Disruptive technologies transform the way we live and work, enable new business models, and provide an opening for new players to upset the established order." (McKinsey Global Institute, 2013: iii)

Energy storage has the potential to revolutionise the energy markets worldwide. Globally, the economic impact of a robust deployment of distributed energy storage is estimated to range between $\$ 90$ billion and $\$ 625$ billion per annum (McKinsey Global Institute, 2013). In the United Kingdom (UK), a recent report indicates that energy storage, together with interconnection and flexible demand innovation, could save consumers $£ 8$ billion per year by 2030 (National Infrastructure Commission, 2016). The full potential of energy storage, however, has not been fully assessed or exploited yet.

Thermal and electrical energy can be accumulated and stored over time using a host of technologies. These technologies allow storage facilities to release the energy on demand to supply services such as heat (cold) or electricity. A total of 31 energy storage projects are currently operational in the United Kingdom, according to the United States' Department of Energy (DoE, 2016). Around $87 \%$ of the projects' total power (3258MW) is stored in electromechanical, traditional pumped hydro storage systems, while a further $12 \%$ of power is contained in flywheel energy storage. The remaining $1 \%$ or so of stored energy is predominantly in electro-chemical storage devices (lithium-ion batteries, 23.7MW) or other technologies (e.g. lead-acid batteries, compressed air storage).

The integration of intermittent renewable technology into the energy systems across the developed world creates challenges, such as the need for payments to curtail excess output, and to generate energy at short notice when renewable generation is below expectations. Energy storage technologies can help to meet this challenge by adding flexibility to the system. On the one hand falling capital costs of energy storage will continue to be a key driver, but costs have some way to go to before this technology becomes the default option. On the other hand the argument for storage is likely to strengthen over time, as distributed and intermittent generation becomes more widespread and the routes to multiple sources of revenue become available. 
Currently energy storage in the UK can rely on around 3 main sources of revenue from at least 14 different revenue streams (Everoze, 2016a; Rocky Mountain Institute, 2015). Energy storage can facilitate greater self-consumption, price arbitrage, and demand management within a time-of-use pricing system. However, more aggregated systems, such as community projects or virtual power plants (VPP), can access revenue streams with even greater value, such as the provision of frequency response services ${ }^{1}$. As a result novel business models have started to emerge to meet the challenge of 'stacking' revenue streams in order to create viable energy storage projects. The companies implementing such business model have however been subject to limitation in terms of regulatory access and access to emerging energy markets as we discuss in more detail in the paper.

There is little consistency, within the literature exploring new business models of energy storage, surrounding the definition of a business model. Nevertheless drawing on the wider business and strategy literature, the key elements of a business model can be identified as: actors and ownership, value and consumers. Boscán and Poudineh (2016) place actors at the heart of business models. While end-users, utilities and third parties broadly define the actors participating in a distributed energy system, distilling every actor from these groups is complex, as their roles are not mutually exclusive and the market is currently in a state of transition (Boscán and Poudineh, 2016; Ofgem, 2015a). For example, energy produced by residential consumers can be aggregated via a third party into a virtual power plant, or consumers can collectively produce energy independently from the grid, replacing the traditional role of an energy supplier. This example further indicates that, as actors collaborate on increasingly innovative business models, ownership of the assets and ability to capture the value generated by storage systems becomes less clear. Actors developing new business models for the marketplace, first and foremost, must create, deliver and capture value for their stakeholders (Casadesus-Masanell and Ricart, 2011; Osterwalder et al., 2009). Nillesen and Pollitt (2016) suggest that value is best created by utilising a variety of revenue streams. In Magretta's (2002) view a business model should tell a story which seeks to encapsulate value-for-money for consumers alongside economic value for stakeholders. Therefore, it is essential to identify the target customers in energy storage business models

\footnotetext{
${ }^{1}$ The National Grid owns and manages the infrastructure that transmits electricity from generators to distributed network operators. According to the National Grid's license it must purchase reserve generation and demand of electricity to balance grid frequency, which fluctuates when generation and demand are not in equilibrium, within $1 \%$ of nominal system frequency i.e. $50.00 \mathrm{~Hz}$ on a second-by-second basis. Other variations include firm frequency response, provided by firms, and enhanced frequency response, which specifies that $100 \%$ active power output is reached within 1 second.
} 
(e.g. generators, network operators ${ }^{2}$, households etc.) and evaluate whether the business model can deliver something that is valued by such customers (e.g. flexibility, aggregation, affordability etc.).

This paper aims to assess the key challenges and opportunities arising for emerging nontraditional business models of distributed energy storage at the city level in the UK. In order to classify the business models investigated in this paper we propose a framework which identifies three main layers according to which business models can be grouped. The first layer represents the level of interconnectedness with the grid. The second layer identifies the business models forming the 'core' of an increasingly distributed energy system. The third layer contains the business models that provide innovative services which enable actors who rely on 'core' business models to 'stack' additional high-value revenue streams. In this paper we also investigate the opportunities for end-users, utilities and third parties to interact and share the risks and benefits from accessing upstream services.

In our investigation of business models we adopt a technology neutral approach and we focus on energy services for domestic users as this is the area where we have seen the most innovative business models emerge. Finally, to provide examples of real-life implementation of non-traditional business models, we present a set of case studies involving the deployment of energy storage technologies to support local energy systems in the UK. Interviews with two key companies involved in the distributed energy projects illustrated in our case studies are used to highlight the emerging challenges and opportunities in this fast-developing sector. We use the UK case studies and the related interviews to identify the key lessons which can be drawn from these pioneering projects by business, local authorities and policymakers.

The paper is organised as follows: in Section 2 we identify non-traditional business models for distributed energy system at the city level. In Section 3 we discuss the contractual arrangements associated with such business models. Section 4 follows with the description of illustrative case studies of innovative distributed energy storage in the UK and the discussion of evidence from stakeholders' interviews, before providing some concluding remarks and policy recommendations in Section 5.

\footnotetext{
${ }^{2}$ In the UK, there are 16 distribution network operators licenced to transport power from the transmission network to consumers (e.g. households, businesses etc.).
} 


\section{Non-traditional business models for energy storage}

At the city level, non-traditional business models are led by three sets of actors: 1) local residential consumers, 2) organisations (e.g. small-medium enterprises (SME), suppliers, local authorities) and 3) district network operators. While non-traditional business models are often treated as independent elements of the energy market in the literature, they are in fact related to one another. In order to better classify the broad archetypes of non-traditional business models we propose a framework which identifies main three layers (or categories).

The first 'baseline' layer includes the business models defined by the traditional environmental and technical interdependencies with the local and national network. Within a traditional energy system, actors (i.e. local customers) purchase and store units of an energy commodity (e.g. using storage heaters, tanks and batteries) delivered 'on-grid' through a regional distribution network or via a private wire (e.g. a combined heat and power district energy system, supported by a large-scale storage tank or battery). Alternatively, customers living 'off-grid' (e.g. rural areas, isles) purchase primary energy sources to store and convert into final energy services. This baseline layer, therefore, represents the business models which deploy energy storage to passive energy users who are largely inactive participants in the energy market. The second layer outlines the 'core' business models which provide innovative city-level solutions to local customers. Prosumers, i.e. actors who consume and generate their own electricity, are commonly recognised as innovative business models which can profit from accessing and using energy storage facilities. Additionally, three other business models can capture higher value revenues and profit from energy storage: third party aggregators, community groups, and municipal suppliers. Finally, distributed network operators (DNOs) could enter third party arrangement to supply storage services, as DNOs can currently only own small-scale generation or storage facilities so would benefit from agreements with other market actors to increase the available storage capacity.

The final layer of business models provides support to the core set by delivering specialised services, some of which enable entry into established markets. This can be either through outsourcing supply licence activities to established suppliers, such as through the provision of technical elements of industry code compliance, under Licence Lite commercial arrangements, or through building a new brand under a White Label arrangement. New markets are also being created where energy can be traded between traditional residential consumers and prosumers (Peer-to-Peer platforms and specialist) using technological 
innovations (e.g. Blockchain) and digital currencies (e.g. Bitcoin). Furthermore other business models allow actors to focus on core business offerings by out-sourcing operations and other activities to multiple service providers, such Energy Service Companies (ESCOs) and software specialists. The business models of Energy services companies, also known as ESCos, relies on the provision of a range of energy related services, which can include storage facilities management, based on contracts with asset owners. This third category of business models (grouped as 'service layer' in Table 1 below) can provide a route to higher value revenue streams that would not have be available otherwise.

Table 1. Local consumer business models

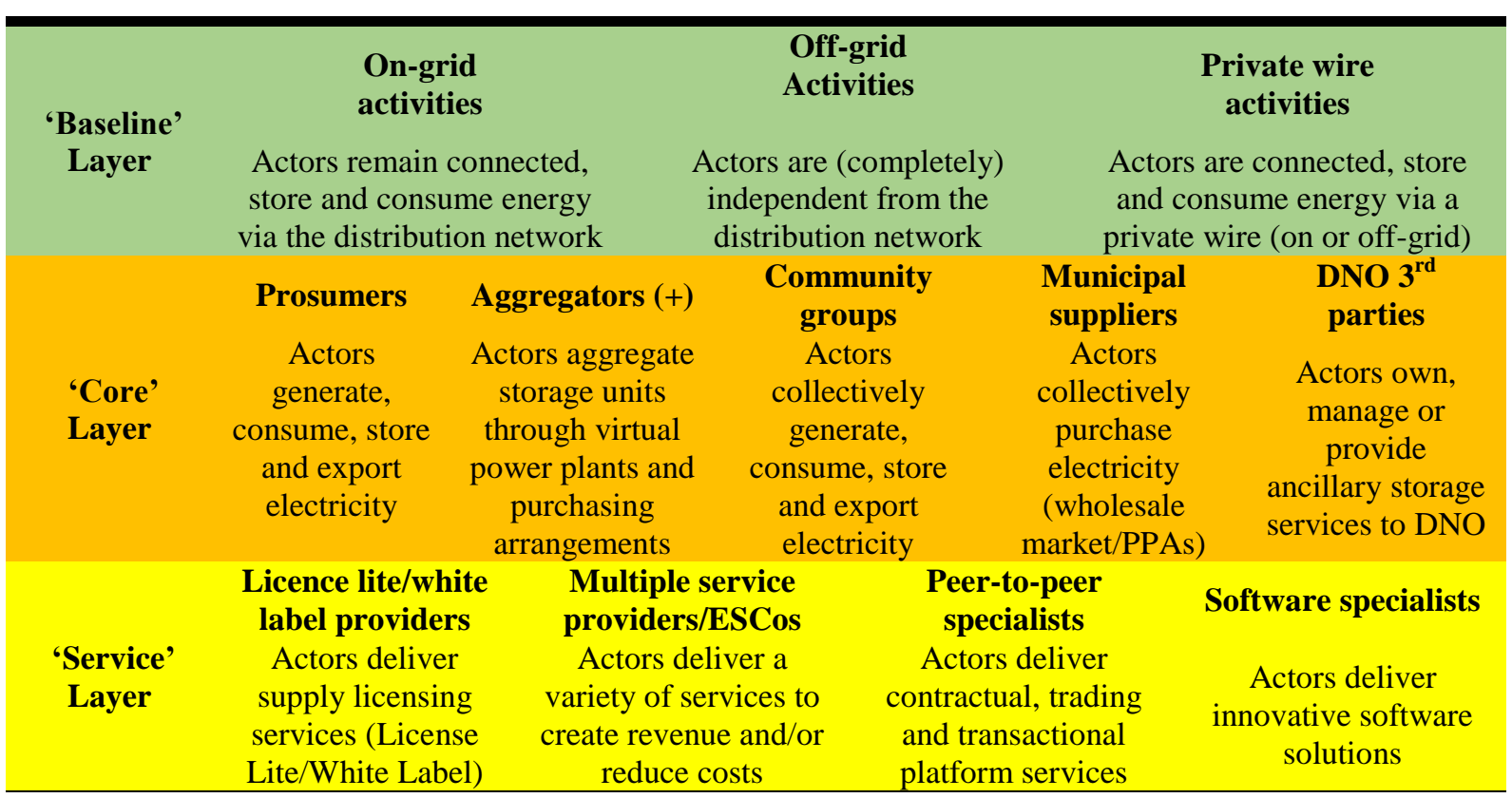

Note: See Appendix for an overview of the value propositions, consumer segments and ownership structures for each business model listed in the table.

In what follows, the 'core' business models are discussed after providing details on the key revenue streams underpinning these models, while we refer to the 'service' layer of business models when contextually appropriate. As will become apparent in the discussion of the case studies, the combination of business models from each layer will ultimately depend on the expected profitability of the project, transaction costs, contractual issues and local sociopolitical, regulatory and spatial conditions.

As the cost of energy storage continues to fall, innovative business models are establishing new routes to creating and capturing value from a variety of potential revenue streams. To date, 14 key sources of revenue have been identified in the literature (see, e.g., (International Energy Agency, 2014; Everoze, 2016a; Rocky Mountain Institute, 2016), which are listed in 
the inner circle of Figure 1. A common feature of all non-traditional business models is the ability to 'stack' several revenue streams together in order to make a profitable case for energy storage located behind-the-meter ${ }^{3}$, 2014). At present, most business models can capture value up to four streams of revenue (Everoze, 2016a). It is important to note however that 'stacking' will naturally increase the costs (e.g. operational, maintenance, transactional etc.) associated with the business model (Regen SW, 2016). Furthermore, the number of feasible revenue streams will be constrained by the system's 'operational availability', i.e. the trade-off between different sources of revenue (Castellano Ruz and Pollitt, 2016). Therefore the optimal set of streams should be chosen according to the mix of revenues which maximises profits.

The ability to access the different sources of revenue will depend on the national institutional framework where the emerging business models are implemented. In the UK context, which is the focus of this paper, there are several sources of revenue that can be accessed by companies that engage in the delivery of flexibility services and in the implementation of the related business models. Since $1^{\text {st }}$ April 2010, owners of renewable and low-carbon generation could apply for Feed-In-Tariffs, which consists of two tariffs: export and generation tariff. The export tariff is currently $5.03 \mathrm{p} / \mathrm{kWh}$, whereas the generation tariff is calculated on the basis of several variables including size of the system and technology installed. As of January $15^{\text {th }} 2016$ the UK Government has reduced the generation tariff for domestic solar photovoltaic (PV) installations by around two thirds (Ofgem, 2017). As a result, the deployment of solar PV at less than $4 \mathrm{~kW}$ has fallen from $34 \mathrm{MW}$ per month to 7MW per month (BEIS, 2017). Despite being closed to new applicants as of $1^{\text {st }}$ April 2017, the Renewable Obligation scheme also remains an important source of revenue for large renewable systems. Renewable Obligation Certificates are allocated to those enrolled on the scheme and procured by suppliers. The suppliers are incentivised to purchase ROCs in accordance with their renewable obligation targets or face a 'buy-out' price.

Since 2014, a key subsidy has been delivered through National Grid's Capacity Market Auctions, where suppliers bid for Capacity Payment Revenues. Winners make themselves available to deliver power at times of system stress and incur a penalty for failure to deliver. Capacity payments can provide a stable source of revenue on the basis of contracts ranging from 1 to 15 years. In December 2016 auction the clearing price the $£ 22.50 / \mathrm{kW} /$ year helped

\footnotetext{
${ }^{3}$ Energy storage can be deployed at the distribution, at transmission level, and behind-the-meter, i.e. at domestic, commercial or industrial sites.
} 
to secure $3.2 \mathrm{GW}$ of storage. Another source of financial capital was the Low Carbon Network Fund, which allocated $£ 500$ million to projects aiming to spur low-carbon solutions that can create efficiency savings for DNOs (see 'DNO $3^{\text {rd }}$ Party' in the appendix). The Renewable Energy Association (2015) identified nine battery projects piloted at the DNO level, including UK Power Networks' Smarter Energy Storage project which, among many other innovative findings, identified frequency response as the most valuable ancillary service for the creation of a viable business model (UK Power Network, 2017). Frequency response services, including Enhanced Frequency Response (EFR) and Firm Frequency Response (FFR), are tendered by National Grid through a competitive auction and remunerated on the basis of the specific service delivered. The EFR auction acquired 201MW of capacity (almost all are storage projects) at an average price of $£ 9.44 / \mathrm{MW}$ of EFR/h. Other services, such as Short Term Operating Service (STOR) and Demand Turn Up ${ }^{4}$, are paid by the National Grid for being available to provide as well as to deliver balancing services.

More recently the UK Government has agreed to reduce VAT to 5\% for battery storage purchased together with solar PV (Solar Trade Association, 2017). Although owners of solar PV cannot enjoy the same reduction if they plan to retrofit their panels with storage, the new rate may bolster the uptake of solar-storage packages by reducing the upfront cost for households. Innovate UK, an organisation sponsored by the Department for Business, Energy and Industrial Strategy (BEIS), has planted seed money into several breakthrough storage projects. For example, Upside Energy and Moixa received funding to investigate the potential for VPPs to reduce network costs by providing balancing and other ancillary services. Funding was also allocated to Powervault which seeks to test the commercial viability of turning second-life electric vehicle batteries into domestic storage units. The UK Government has also announced an additional $£ 246$ million for investment in energy storage (BEIS, 2017).

Prosumers can potentially access three main sources of revenue: backup power, selfconsumption, and retail market arbitrage (the highlighted area in Figure 1). An energy storage system can work as a reserve to be discharged, for example, in the event of a blackout. In addition, it can be used to optimise the consumption of renewable energy and minimise the

\footnotetext{
${ }^{4}$ The National Grid's STOR service procures reserve power (i.e. generation and demand reduction) to ensure that it can respond in the event of actual demand exceeding predicted demand and/or plant(s) temporarily going offline. In contrast, the National Grid's Demand Turn Up service aims to eliminate excess power on the grid by incentivising increased demand and/or reduced generation.
} 
purchase of energy from the grid through demand shifting and peak shaving (Everoze, 2016a). However, taking costs into account, Kalilpour and Vassallo (2015) suggest that owners of energy storage would be better off by remaining connected to the grid as they will generate extra revenue from Feed-In-Tariffs. There is potential for prosumers to earn additional revenue by engaging in retail market arbitrage, i.e. purchasing electricity when the price is cheap and selling at a higher price. Powervault (2016) estimated that up to $35 \%$ of household bills can be saved through self-consumption (20\%) and purchasing electricity offpeak from the grid $(10-15 \%)^{5}$. A broader range of retail arbitrage opportunities may emerge for prosumers once smart meters and flexible tariffs become widespread.

Figure 1. Potential revenue streams for energy storage

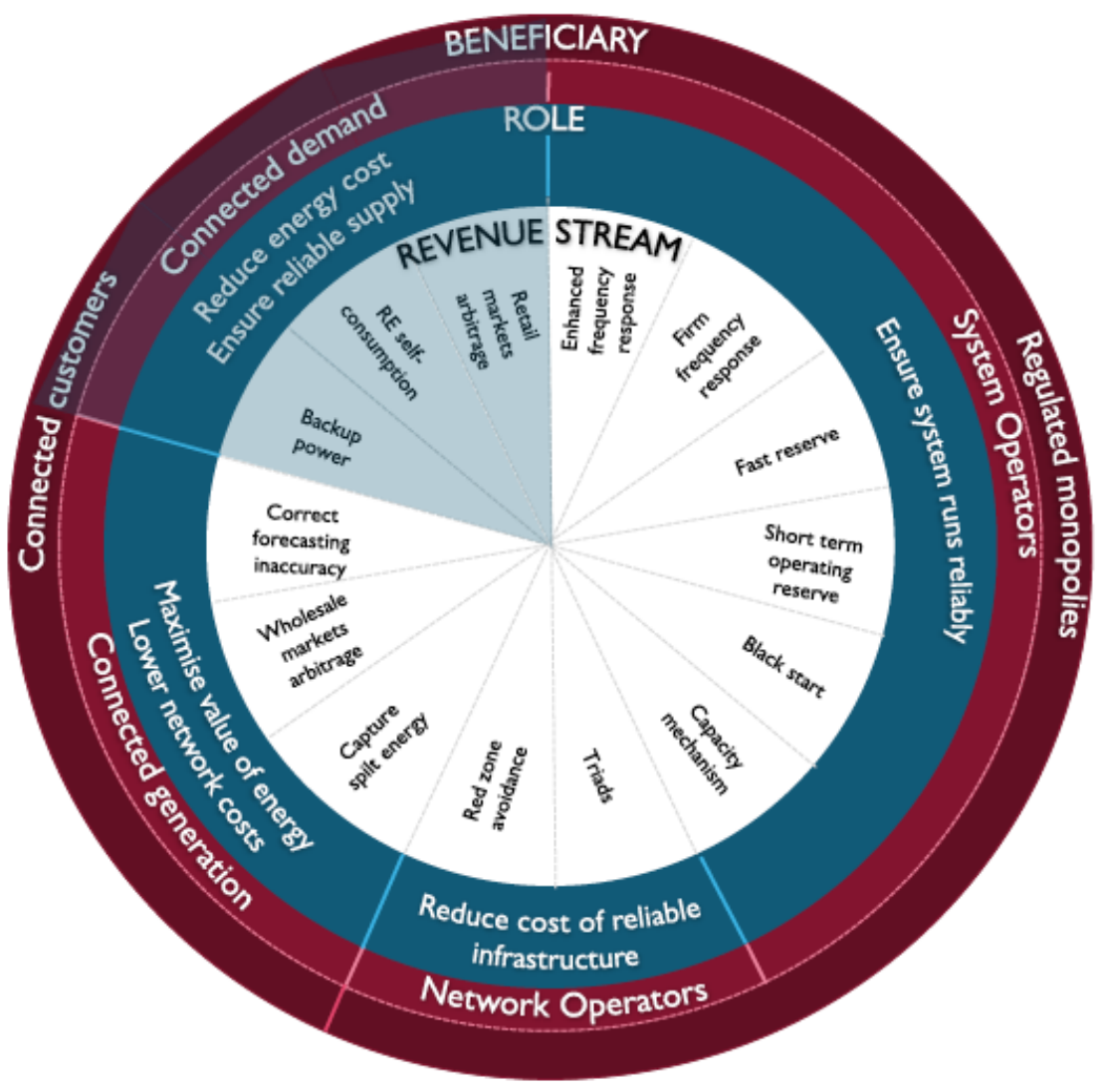

Source: Everose (2016a)

\footnotetext{
${ }^{5}$ In comparison, Moixa (2016) claimed that their competitive solar and storage bundle can save households up to $60 \%$ on their electricity bills. Powervault and Moixa however do not provide details on how these figures are calculated, except for implying that they are based on an average household and that they represent an upper bound estimate.
} 
Aggregation brings together local residential consumers and prosumers, who by themselves may not have the time, money or technical capability to negotiate multiple complex contracts, and provides an access route to high value revenue streams by creating a 'virtual power plant' (VPP) (see 'Aggregators' business model in the appendix). While third party aggregation is crucial to help consumers access multiple benefits, it also raises questions surrounding ownership and control of the stored electricity (Solar Trade Association, 2016). For example, residential consumers rationing their energy use, potentially require alerts to inform them of up-coming discharge cycles (i.e. time when the aggregator withdraws electricity), especially during the winter.

In contrast the 'Aggregators Plus' business model offers consumers the option to install a solar-storage package free of charge, potentially de-risking the upfront payment for consumers. North Star Solar (2016) are pioneering this model in the UK, offering solar panels and storage at zero upfront cost alongside free LED lightbulbs, while covering insurance and ongoing maintenance costs. For a more detailed discussion of this project and the company's view about market opportunities and challenges see the discussion contained in the North Star Solar case study and interview in section 4.

All the business models presented thus far are only possible through innovative balancing and demand optimisation technology. Non-traditional business models therefore will play an essential role in supporting aggregation systems through the development of cutting edge software and data storage facilities (see, e.g., the 'Software Specialists' model in the appendix).

There are several variations on the third party aggregation, or virtual power plant, model (see 'Aggregator+' in the appendix). Delta-EE (2016) discuss the most advanced model which delivers a whole suite of revenues: 1) avoiding peak (flexible) tariff charges, 2) reducing peak demand, 3) optimising self-consumption, 4) access to green subsidies, and 5) the option to sell electricity one-day ahead, which puts the choice of aggregation in the hands of the consumer. The Rocky Mountain Institute (2016) further shows that energy storage projects are only profitable when the system delivers a stack of high value ancillary services, such as frequency regulation and load following, in addition to the standard primary services. In Appendix B of the Massachusetts Institute of Technology (2016) report on the Utility of the Future more than 100 international case studies are reviewed and organised on the basis of several archetypes which relate to the nature of the services provided and to customer 
segments. This allows the authors to identify the most likely sources of revenue associated with different business model archetypes.

While advanced aggregation systems provide a route to high value revenue streams, there are two fundamental caveats: regulation and revenue cannibalisation. On the one hand, Castellano Ruz and Pollitt (2016) argue that stacking may be limited by the fact that some revenue streams are likely to be restricted or inexistent due to market regulation. On the other hand, they also note that, even if stacking were possible in a completely deregulated market, fierce competition could cannibalise some revenue streams. This is likely to affect the high value streams with few contracts/auction tenders which storage projects rely on to remain profitable over time (Regen SW, 2016). If non-traditional business models are to survive in a deregulated and competitive market with no subsidies, then they will have to entice residential consumers by creating significant revenue to reduce the payback period, but also innovate in order to capture and 'stack' the value in a competitive market.

In terms of value creation, the business model for community energy is similar to third party aggregation (see 'Community Groups' in the appendix). Although third parties and community models may stand in direct competition, community schemes are more likely to operate within a specific local area and/or focus on vulnerable social and economic groups (Ofgem, 2015a). The fundamental difference between these two business models lies in the 'local community ownership and partnership' element. Community projects are often nonprofit organisations with a strong commitment towards funding local charities and ecological projects, creating jobs and training schemes to support and enhance local growth, improve local air quality, while reducing consumption and energy bills in order to tackle fuel poverty.

To date there are around 10 community-owned and 6 third-party-owned energy storage schemes in the UK (US DoE, 2016). Smart Energy Special Interest Group (2013) have suggested that community energy schemes could generate between $1.6 \%$ (baseline scenario) and $15 \%$ (maximum growth scenario) of the UK's total capacity by 2030 , though not all projects will involve the use of storage technology. Community energy projects have gained pace in the UK in recent years since the introduction of the Feed-in-Tariffs and the Community Energy Strategy in 2010 and 2014 respectively, but face greater uncertainty since the reduction in Feed-in-Tariffs (Smart Energy Special Interest Group, 2013; Simcock, Willis, and Carpener, 2016). 
A variety of innovative methods are used to finance community energy projects. Our case studies, discussed in more detail in section 4 below, suggest that community projects use crowdfunding as well as making local/public share and bonds offers which typically advertise projected annual returns between $3 \%$ and $7 \%$. This is a reasonably attractive prospect compared to the historically low rates on offer at retail banks, though one should bear in mind the rate reflects additional risk. In some cases, community projects receive funding from local trusts and charities, while other projects are financed by the private or public sector, such as government grants or subsidies, the European Development Fund, and/or commercial bank debt. Ethical banks, such as Triodos, also appear to be a popular source of 'green' finance.

Community storage business models are also innovative in their approach to how consumers interact and consume energy. For example, in Europe, community projects are leading the way in peer-to-peer trading (see the appendix for a description of 'Peer-to-Peer Specialists'). In the future, it is conceivable that it could become commonplace for residential consumers to trade energy within a community using digital 'cryptocurrencies' (e.g. Bitcoin), whereby the transactions are processed via online decentralised marketplaces (such as 'Blockchain' and Ethereum. In the UK, one of the first community storage models aims to generate multiple streams of income through, for example, 1) balancing and support the grid network at peak times, 2) the Transmission System Use of System (TSUoS) and Triad charges ${ }^{6}$, and 3) FFR (see ERIC project in Section 4). Around the same time, Open Utility, a software company, began trialing a nationwide distributed energy network (in partnership with the supplier, Good Energy), which affords consumers the opportunity to purchase and trade locally generated electricity (Open Utility, 2016).

In order to create a profitable business model the household, third party or community must remain connected to the grid. There are several reasons for this, including: 1) the sale of electricity to the grid (e.g. Feed-in-Tariffs, retail or wholesale market arbitrage), 2) emergency energy demand, 3) commercial aggregation models which use suppliers to organise the payment of solar-storage packages/tariffs, and 4) the ability to increase competition in the energy market through switching. The Smart Energy Special Interest Group (2013) argues that community energy schemes will continue to exist alongside the

\footnotetext{
${ }^{6}$ Medium to large companies, using half-hourly metering, are charged (TSUoS) by the National Grid in order to invest in and maintain the transmission network. Triads charges are implemented according to the three halfhour periods of highest demand between November and February. A company is exempt from TSUoS charges for a whole financial year if it does not consume electricity within a Triad period.
} 
current traditional networks, not least because expanding beyond local systems will require expensive network modifications. However a number of 'off-grid' systems, such as island grids, have completely broken away from the traditional model using community solarstorage systems. (See 'Off-Grid', 'On-Grid' and 'Private Wire' descriptions in the appendix). Most recently, Hitachi and Moixa plan to roll out a Smart Energy Island model in the Isles of Scilly to tackle fuel poverty and bolster energy independence, with a vision of exporting this model across the world (Moixa, 2017).

Another variant of the community energy model is the 'Municipal Supplier' (see appendix), of which few are active in the UK (Ofgem, 2015a). We compare the well-known Bristol Energy and Nottingham Robin Hood Energy models as they highlight the main features of municipal suppliers. Although fully licenced to supply the whole energy market, both provide discounts to residents within their designated municipalities. And while these suppliers are owned by their respective City Councils, it is easy to imagine other forms of ownership such as communities, joint ventures or white labels (Ofgem, 2015a) (see 'White Label' description in the appendix). The central value underpinning this business model is the fact that they challenge incumbent suppliers by undercutting their energy tariffs. Additionally, Robin Hood Energy is run as a non-profit supplier, focusing solely on offering energy prices below the incumbents, while Bristol Energy earmarks its profits to local energy projects (e.g. forming PPAs with local renewable generators and rolling out smart meters) and social projects (e.g. supporting local charities to help vulnerable and fuel poor consumers). Although these municipal suppliers do not directly own storage technology, it is possible that similar models will either own storage technology or recycle profits into local storage projects in the future.

There are two convincing non-traditional district network operator business models which have been developed by UK Power Network (2016): the 'DNO contracted' model and the 'contracted services' model (see discussion of the 'DNO Third Party' model in the appendix). However, the current regulatory arrangements prevents DNOs from owning generation over a specified capacity, including storage technology, which is currently defined as generation due to the role traditionally played by pumped hydropower in the market. Such regulatory conditions favour joint ventures or partnerships between the DNO and a third party. In the first model, the DNO owns the technology and contracts the third party to maximise profit through the management and control of ancillary services. Whereas the second model puts the ownership of the storage technology in the hands of the third party and the supplier 
contracts the ancillary services. The latter may be more appealing if larger storage units can be purchased, allowing economies of scale, and if the contractual costs are lower than the additional revenue gained from such an agreement.

Network cost deferral is an additional factor that might increase the attractiveness of energy storage for DNOs. The distributed electricity network is going through a rapid transition from the traditional DNO model, characterised by a unidirectional flow of power, to a distribution system operator (DSO) in order to cope with a bidirectional flow of electricity from generators to consumers and from prosumers back to the grid. The network must be transformed to make sure that it remains safe and reliable and this requires investing in the network to tackle an increased risk of power cuts. The DSO can defer costly network reinforcement by installing energy storage. The UK Energy Research Centre (2017) argue that storage tends to supply services that 'relieve' rather than stress the grid and should be compensated as such or pay less to use the network. Similarly, storage has the potential to defer or avoid expensive grid reinforcement. However, Poudineh and Jamasb (2014) suggest that it is not only difficult to price the deferral of network investments but many technical, economic and regulatory challenges prevent DNOs from tapping into this service.

The discussion of UK case studies in section 4 focuses mainly on the aggregator model and on community schemes in order to provide evidence about how different revenue streams are accessed and in order to investigate some of the emerging regulatory and competitive challenges in this fast-developing sector.

\section{Contractual arrangements and sources of revenue}

Stacking the revenue streams is a necessary element of a successful business model for energy storage but its success depends on a variety of factors, including contractual arrangements and regulatory barriers. This section discusses these issues in the context of business models for energy storage.

In one way or another, the business models discussed above rely on complex contractual arrangements. For instance, small energy storage projects, such as prosumers and communities, may not have the expertise to facilitate and broker a purchasing power arrangement offered by suppliers or enhanced frequency regulation contracts tendered by the 
transmission system operator. Third party aggregators and multiple service providers can fulfil this role.

Contracts are crucial as they will underpin not only the relationship between the consumer, third party and supplier, but also the ability to provide high value services through market processes, such as participating in an enhanced frequency response tenders. He et al. (2011) discuss optimal contracts in the context of energy storage services. The authors argue that, unlike typical business models which assume that contracts will be procured on a case-bycase basis, storage capacity could be awarded to different actors in several stages through auction mechanisms. The optimal set of contracts would however rely on the actors coordinating their load profiles so that electricity can be withdrawn for the contracted capacity at optimal time horizons. One possible challenge to this arrangement is the need for information to be shared between actors which may be restricted due to regulatory and competitive factors, or privacy concerns.

Another potential issue flagged up in the literature is contract length. Smartest Energy (2016b) suggest that short contract lengths may deter investment in the energy storage market because of the uncertainty surrounding future revenue streams (UK Power Networks, 2013; NIC, 2016). For example, the enhanced frequency response contracts tendered by National Grid in the UK last only 4 years $^{7}$ (Everoze, 2016b). Yet, despite the relatively short contract length, the participation of energy storage projects was significant in the first tender, with only 8 firms with battery storage projects equivalent to 201MW winning contracts, while over $1.2 \mathrm{GW}$ of storage projects were denied a contract (KPMG, 2016). This suggests that for storage companies the relatively short contract length might have been overshadowed by the potential revenues from supplying EFR and other ancillary services, and more importantly getting a foothold in the market (KPMG, 2016).

As DNOs can only own storage technology within a specified capacity, equivalent to a 'small generator' (Castellano Ruz and Pollitt, 2016), they could form a partnership or contractual arrangement with a third party to circumvent this issue. However, transaction costs may prevent such arrangements from taking place. With regard to energy storage facilities the DNO could follow two central approaches: they can either own the energy storage

\footnotetext{
${ }^{7}$ It is worth mentioning that the grid usually offers 1 -year contracts, it has been suggested that the Grid recognises that ancillary services are the primary revenue stream for battery storage and therefore offered an extended contract in this tender (New Power, 2016).
} 
technology and contract a third party to manage the services, or contract the services from the owner of energy storage.

The first approach reduces transaction costs due to the fact that the DNO owns the storage system, although within the regulatory limits. Contracting a third party with expertise in energy storage management and optimisation could increase the DNO's profits if they do not have such skills in-house. Though the revenue from this arrangement will be shared to some extent between the parties, it is likely to be largely appropriated by the DNO due to a stronger bargaining position, as it owns the technology and must recoup the initial capital costs. The third party therefore must evaluate whether the agreed share of revenue is large enough to cover its own investment costs. Although transaction costs are low in this case, the investment costs and risks are borne by the DNO. These factors need to be weighed against the potential revenue, in order to establish whether this approach represents a viable business model. In contrast, the second approach potentially increases transaction costs, while transferring the installation/maintenance costs and ongoing risks to the third party. Further, the third party must invest in an energy storage system located close to the DNOs infrastructure. Third parties are likely to be wary of relationship-specific decisions without protecting their investment with a contract. However, as Hart (1996) suggests, the contractual arrangements will largely be incomplete due to their complexity, especially in novel markets such as this, and might need amending as the partnership evolves. This is problematic from the point of view of the third party for two key reasons. Firstly, the third party may be locked into the arrangement if the storage technology is immobile or if there are no other contracts available outside the arrangement. Secondly, transaction costs may arise from the resources and learning costs associated with bargaining over future trade agreements (Hart, 1996). However, if the third party is sufficiently 'locked-in', the DNO's bargaining position will be strong, increasing the likelihood of the DNO appropriating profits from future trade. The increased transaction costs and uncertainty surrounding revenue may decrease the willingness for storage owners to enter into such an agreement, and lead to an inefficient level of investment in energy storage technologies as a consequence.

A slightly different variant of the second model seems to work well for municipal suppliers: for example the Bristol Energy offers purchasing power agreements (PPA) to community energy groups, developers and generators. All third parties own the capital, but instead of supplying a range of services to the transmission grid as discussed before, they sell renewable 
electricity to the municipal supplier. The contract is not exclusive and therefore has limited 'lock-in' effects, unless there are no other PPA arrangements in the market. However, given the fact that the municipal supplier is owned by the City Council the prospect of postcontractual opportunism is relatively low as they do not have shareholders to satisfy. This arrangement is interesting as it suggests that the contracted services model is a viable model for municipal as well as private suppliers and therefore likely to be a promising model for storage, too.

Contractual arrangements are particularly relevant in the context of the role of ESCos. Hannon and Bolton (2015) outline strengths, weaknesses and policy implications for three distinct ownership models through which ESCos interact with local authorities: the local authority owned at 'arms-length' model; private sector owned concession agreement model; and the community owned and run model. Underpinned by 53 semi-structured interviews with key stakeholders in the UK the authors suggest that the model of choice reflects the local authorities' appetite for risk and their technical expertise. The key trade-off between the fully owned and concession or community owned models lies in gaining greater control over the management of the energy project's finances and goals and assuming the associated risks. From the ESCos' perspective, partnering with a local authority provides exclusive access to

public buildings with high energy densities owned by one contractor, thereby reducing transaction costs (e.g. information, planning permission etc.), while at the same time eliminating competition.

In the next section we describe existing UK-based projects where innovative business models have been implemented. We also use interviews with two of the companies involved in this market to better understand the factors driving their choice of specific business models. This allows us to assess the key success factors in these projects, by drawing on issues discussed in previous sections, and to identify the main challenges which are currently being encountered or which will need to overcome in the future in order to expand the companies' presence in the market.

\section{Case studies evidence on non-traditional business models}

The following case studies focus on the most innovative city-scale business models identified in the UK. The description of the case studies is followed by a discussion of extracts from interviews with representatives from Moixa Technology (Chris Wright, co-founder and CTO) 
and NSS (Peter Sermol co-founder and Managing Director), who have been involved in some of the projects discussed below. Based on these interviews we attempt to assess to what extent the theoretical opportunities and challenges identified in the existing literature are applicable to our case studies, and to draw lessons from the experience of the companies which have established themselves in this emerging market using innovative business models.

The ERIC Project (Oxford, Rose Hill, England)

The ERIC (Energy Resources for Integrated Communities) project, led by Moixa and Bioregional, has received support from a number of stakeholders including Oxford City Council and British Gas. The project received $£ 1.2$ million of investment over two years, largely from the Innovate UK government scheme and in part (£2000) through a crowdfunding scheme run by a local school. In 2015, Moixa announced that thirty $2 \mathrm{kWh}$ Maslow storage units were installed, equivalent to $60 \mathrm{kWh}$. The most recent update suggests between 80 and 90 households have installed the Maslow storage unit in their homes (i.e. over $160 \mathrm{kWh}$ ). The storage units were installed alongside solar panels in 60 households and, together with over 100 solar panels, located at the local primary school. In doing so, the project anticipates that it will demonstrate a menu of value for battery storage. This menu includes the potential for aggregation services, using distributed storage units, to reduce household energy bills (estimated to be around $£ 120$ per year) and increase self-consumption of renewable generation. The project further plans to access and stack revenues from ancillary network services including Triad charges, STOR and FFR. Extra value will be created by using innovative software and a virtual energy platform (GridShare) to help balance local demand and supply through time shifting services and peak load reduction. To date the ERIC team estimates (based on 50 solar-storage packages) that over $47,000 \mathrm{kgCO}_{2}$ was saved within a year and the local primary school has eliminated $20 \%$ of its electricity usage achieving estimated savings of $£ 11,000$ per year.

The North Star Solar Project (Stanley, County Durham, England)

North Star Solar, in cooperation with Stanley Council, are planning a colossal project in Stanley, County Durham with an estimated cost of $£ 110$ million (around $£ 5000$ per home) financed by institutional investors. The project team plans to roll out a solar-storage-LED package for up to 22,000 households (around 35,000 residents). Importantly, the team aims to 
install batteries (manufactured by Sonnen, Leclanché or Build Your Dreams) that are optimal with respect to the features of the specific households and housing characteristics. Although the total battery storage capacity is expected to be around 66MW (installed alongside solar panels with an average power output of $3 \mathrm{kWp}$ ), the actual scale of household participation in the project is yet to be determined. The key feature to entice household participation lies in the fact that the solar-storage-LED package will be installed at zero upfront cost and maintained for 20-years at no cost to the customer. Capital costs are recouped using the savings made on the households' energy bills. North Star Solar plan to help households with relatively high energy costs, particularly the fuel poor ones, to save at least $20 \%$ on their energy bills per annum over the 20-year period, after which the customer owns the system ${ }^{8}$. From the outset, the households will save a fixed amount per month, anticipated to be around $£ 25$ depending on household consumption, to achieve an (aggregated) minimum saving of $20 \%$ per annum. In order to help deliver these savings, North Star Solar will generate revenue from Feed-In-Tariffs and possibly venture into aggregated ancillary services in the future.

\section{Western Power Distribution SoLa BRISTOL (Building, Renewables and Integrated Storage to Overcome Network Limitations) Project (Bristol, England)}

The 3-year SoLa Bristol project (2013-2016), led by a consortium of partners including Western Power Distribution (WPD), Siemens, Bristol City Council, and the University of Bath, received $£ 2.8$ million funding from the Office for Gas and Electricity Market's $\left(\right.$ Ofgem $\left.^{9}\right)$ Low Carbon Network Fund. This was a relatively early and innovative project that aimed to explore the value of energy storage at the domestic, commercial and DNO level of the energy system with funding form a mixed set of sources.

Moixa's solar-storage package was installed in 26 houses, 5 schools and an office: a $4.8 \mathrm{kWh}$ battery pack was installed in the homes; and, an $18.4 \mathrm{kWh}$ battery was connected to the schools. In addition, the homes were installed with solar PV with the power output ranging between $1.5 \mathrm{kWp}$ and $2 \mathrm{kWp}$ (excluding one home installed with $3.4 \mathrm{kWp}$ ). One key feature of this project arose from the ability of the DNO (WPD) to aggregate the batteries and provide network management services. However, the findings suggest little reason to support this method over conventional reinforcement or demand management options due to the initial

\footnotetext{
${ }^{8}$ It is important to note that the 20-year period matches the Feed-in-Tariff contract length. To meet this target, North Star Solar assumes electricity prices and inflation rise by around $6 \%$ and $2.5 \%$ per annum respectively. Moreover, North Star Solar promise to keep the increase in electricity bills in line with, or below, inflation. ${ }^{9}$ Ofgem is the independent national regulatory authority for the gas and electricity market in Great Britain.
} 
capital cost of the battery system (WPD, 2016). It is worth noting that several factors may have contributed to the insufficient network deferral benefits, including the fact that the penetration of batteries was perhaps too low and any potential change in network demand was not observed in the data.

Our semi-structured interviews with the co-founder of Moixa and the co-founder of North Star Solar, conducted in July 2017, have indicated that the companies' business models involve three main areas of market activity represented by: the provision of ancillary services, utilities-size activities (including peer-to-peer services and participation in the Electricity Balancing System ${ }^{10}$ ) and support for local grid. One of the key priorities for these relatively young and comparatively small-sized companies is associated with delivering the maximum benefit for households, which is where most of their value proposition lies:

"Our model works on the basis that we give the house everything it needs from the battery. So, saving all of its self-generating electricity and time-shifting off-peak electricity for the balance. Over and above that any extra battery capacity we can use for ancillary services." (NSS).

"Obviously our first priority is ensuring that customers get maximum possible benefits from solar-storage because that is where a lot of the value lies and at the same time we are developing other models around services of one kind or another that will enable to offer extra benefits, extra revenues to the customer." (Moixa).

Despite the potential financial benefits some objections and concerns could be raised by residential consumers due to the long term commitment required to recover the cost of the technology:

"We haven't really had objections yet. Although we expect pushback in the form of that it is a 20 year commitment." (NSS)

Other potential objections raised by residential consumers include the complexity of (and time required for) the installation and the size of the devices installed in the property, however, this issue has been factored into the design of small scale batteries (e.g. all-in-one battery and inverter):

\footnotetext{
${ }^{10}$ The National Grid's Electricity Balancing System (known as the Balance Mechanism before 2016) balances supply and demand in real-time over half hourly periods.
} 
"I guess the objections have tended to be around, (...) there is another device in your home and it takes up a bit of cupboard space or whatever. But on the whole, actually, there has not been an issue for people because we have been careful to design our systems to be as compact as possible" (Moixa).

Our interviews revealed that revenue stacking is considered feasible using behind-the-meter systems, as within these systems it is possible to build extra value through ancillary services, such as frequency response services which have a trivial impact on end-users. For other companies however ancillary services still represent a developing market because the choice of ancillary services can have an impact on the battery life, therefore the choice of technology and many other factors need to be accounted for. The ability to stack revenues across different services requires a higher level of effort and experimentation, made possible by being actively engaged in the existing UK-based projects discussed above.

"Largely what we have done in project ERIC is to test a number of innovative [services--that is] peer-to-peer energy sharing. (...) So we've done it for real on the actual systems but in terms of billing process we've modelled it. And so, I think there is a sense in which one of the things that has been revealed that behind-the-meter storage has much greater access to stacking revenues because you already have a customer so you can always sell the energy to the customer in their home - technically - and anything [on top] of that is going to have more value than that if you are going to choose to do it." (Moixa)

The ERIC project, mentioned above, represents an example where peer-to-peer services have been trialled on actual systems while modelling the billing process. As this is a demonstration project involving non-traditional billing arrangements, which are subject to potential errors of measurement and calculation, it would be complex and legally challenging for young and small sized companies to enter into fully-fledged billing contracts with the local prosumers, as this would involve unnecessary legal and regulatory costs in the initial phases of project development. Similar concerns about legal and regulatory challenges are also mentioned in other parts of the interviews reported below.

Emerging companies are also looking into how to relieve stress on the grid from more distributed generation (e.g. solar PV) and distributed load (e.g. Electric Vehicles). Projects are currently being developed to test whether stress can be absorbed by co-locating energy 
storage next to solar-PV to assess whether solar-storage is cheaper than extending the current distribution network.

"The local grid is going to come under an enormous amount of strain, as we get more and more distributed generation and when we get more distributed load-EVs being the obvious distributed load and PV being the obvious distributed generation. (...) so (...) what if we install storage alongside solar and demonstrate that storage can absorb excess solar at peak times' enabling more distributed generation to be installed, so easing the strain on local grids." (Moixa)

The success of emerging business models has been made possible in some cases by addressing finance issues in an innovative way:

"So I would say one of the challenges for battery storage to get off in a meaningful way is for it to be debt financed, which is basically what we've done (...). So having established that we could finance it with debt it all means that we can generally give people savings." (NSS)

"Convincing the debt capital markets of the viability of solar and battery storage. It's not as much the viability, it's making them believe in it to the extent that they are going to finance it." (NSS)

As the project used as case studies and discussed in the interviews are pioneering projects in this area of the energy system, projects delivering fewer sources of revenue with energy storage are likely to be developing a proof of concept, in order to demonstrate different interacting technologies or to establish a foothold in the market, by deploying loss leaders, at least in the short run.

Our interviewees also indicated that it is possible to achieve revenue stacking but with some limitations. While our interviewees can see potential profitability in the provision of ancillary services they also highlighted the high degree of uncertainty which still characterises these markets. For instance National Grid's current review of electricity network charging could impact future profitability, as could the Department of Business, Energy and Industrial Strategy's proposal to de-rate energy storage with short duration periods in the capacity market. 
"Uncertainty is huge because it doesn't give us a place to stand and revenues that we can guarantee to our clients which is very important if we're trying to simplify things" (Moixa).

In addition to market uncertainty companies adopting innovative business models have to contend with regulatory challenges, such as the lack of half-hour metering for domestic consumers, due to slow progress towards full rollout of smart meters, which limits their ability to extract value from their assets and stack revenue:

"Well, half-hour metering for domestic is a huge block on innovative business models, so it's a massive block on imbalance trading and peer-to-peer energy (...) enabling cost free halfhour settlements as part of a smart meter program is absolutely vital.” (Moixa)

Furthermore the limited amount of capacity which can be offered on the basis of domestic prosumers' aggregation represents an obstacle when trying to access some of the potential revenue sources:

"And then, there are regulatory blocks around ancillary grid service markets (...) because you really need a low barrier to entry (...) because we're really small in terms of the energy market (...) which allows us to come in and get to the next stage without being British Gas (...) Even the National Grid's recent drop from 10MW to 1MW around Frequency Services that's still a lot when you are looking at domestic aggregation." (Moixa).

The development of the first distributed energy with storage projects in the UK has benefitted from successful partnerships between emerging companies and from local councils facilitating the deployment of storage technology:

"Stanley Town Council in County Durham said yes in a different type of deal, no social housing, but marketed to their private residential, owner occupiers. (...) We always work on the basis of profit sharing. So we share the profits with the partner. The partner who are with at the time - a housing association or local authority. Given that all local authorities have had severe amounts of cutbacks from central Government over the last seven years, offering to share revenues has been well-received." (NSS)

"So very few of the social landlord tenants are used to the dashboard (...) but on the whole this is something that has been provided more usually (...) in collaboration with a project and the council and us have chosen to have this technology." (Moixa) 
While working in partnership with local councils and utilities have been among the key factors for the projects' success, our interviewees have indicated that complex contractual relationships and the lack of in-house legal personnel can be challenging for emerging companies:

“(...) Moixa's GridShare contracts are going well as are the contracts with utilities such as Scottish Power. However, navigating the maze of contracts around ancillary services is really hard for SMEs (who are at the beginning and trying to aggregate relatively small amounts) as these markets are set up for a world dominated by relatively large customers who have the resources to sit around the table with a big team of lawyers and there is enough money on the table that it's worth the effort." (Moixa)

Overall the assessment of the current projects by our interviewees has been positive with important lessons learned about practical and regulatory challenges. The outlook for distributed generation with storage is also optimistic according to our interviewees, as a result of technological innovations which promote cost reductions, acquired experience in peer-topeer modelling and in deploying the technology, and the gradual removal of regulatory barriers.

\section{Conclusions}

This paper has sought to identify some emerging non-traditional business models of distributed energy storage at the city level, which have been illustrated through representative case studies in the UK. A review of the literature on business models for energy storage reveals that four central elements are critical in order to define and compare non-traditional business models of energy storage: actors, value, consumers, and ownership. Our analysis of the existing literature has allowed us to identify three layers of non-traditional business models at the city level.

After discussing the potential contractual issues which arise in the deployment of innovative energy systems at the local level, we have selected some case studies of projects being deployed in the UK to illustrate how different business activities have been successfully developed in areas with high penetration of generation from renewable sources. The chosen case studies illustrate how the different business models have been able to achieve financial viability by providing a range of energy services and accessing different revenue streams. The analysis of the case studies was further supported by evidence from interviews with 
representatives from two companies which are actively involved in some of the selected illustrative case studies.

Although each business model is unique and will only be relevant given local characteristics, the common goal for all business models is to create, deliver and capture a 'stack' of revenues to offset the relatively high costs of energy storage. The initial analysis of emerging business models in the UK market has led us to conclude that, in order to become more established, non-traditional models will have to overcome several contractual and transactional issues, as well as other outstanding market and regulatory barriers which currently prevent the key actors from exploiting the full market potential of their assets, particularly for relatively small and less established companies.

More specifically, the results of our analysis of case studies of innovative business models in the UK, supported by interviews with company representatives, allowed us to identify three main revenue generating activities which support the commercial viability of distributed energy systems in this market: provision of ancillary services to the grid, of utility services to prosumers (aggregation and peer-to-peer trading) and of support to the local grid to avoid costly network reinforcement. Our cases studies and interviews have illustrated that actors in the emerging UK energy storage markets have access to sources of revenue which lack in other countries but, despite that, full engagement into all areas of the markets and the ability to exploit the full range of revenue streams have been limited by regulatory challenges and political uncertainty.

Our analysis also identified the importance of well-functioning partnership arrangements with local authorities as one of the key success factors for residential energy system with storage. While the set of revenues and market opportunities accessible to innovative energy companies is still expanding, including the ability to provide peer-to-peer trading services to consumers, they still face barriers due to the size of capacity that can be aggregated and to the complexity of contracts that are required to operate in partnership with more established and better resourced companies.

As a result of our analysis, our recommendations to policy makers who aim to promote competition in this sector through the development of innovative business models would be to provide support for the introduction of technology which facilitates transactions and aggregation across prosumers, and to remove the regulatory barriers which currently prevent 
smaller and less established companies from accessing and competing effectively in the emerging markets for energy services which tend to be dominated by established and less innovative incumbent suppliers. 


\section{References}

Bale, C. and Roelich, K. (2015). Municipal energy companies in the UK: motivations and barriers.

Boscán, L. and Poudineh, R. (2016). Business Models for power system flexibility: new actors, new roles, new rules. Chapter 19 in FP Sioshansi (ed.), Future of Utilities - Utilities of the Future: How Technological Innovations in Distributed Energy Resources Will Reshape the Electric Power Sector. Academic Press, Incorporated, Amsterdam: 363-382.

Casadesus-Masanell, R. and Ricart, J. E. (2011). How to design a winning business model. [Online] http://www.bmg-businessconsulting.com/wp-content/uploads/2012/09/How-toRedesign-A-Winning-Business-Model.pdf (Accessed 18 November 2016).

Castellano Ruz, F. and Pollitt, M. (2016). Overcoming barriers to electrical storage: comparing California and Europe. Cambridge Working Paper in Economics 1629.

Chmiel, Z. and Bhattacharyya, S. C. (2015). Analysis of off-grid electricity system at Ilse of Eigg (Scotland): lessons for developing countries. Renewable Energy, 81: 578 - 588.

Delta Energy and Environment (2016). How will energy storage be deployed? Energy storage research service, White Paper.

Department of Business, Energy and Industrial Strategy (2017). National statistics: solar photovoltaics deployment. [Online] https://www.gov.uk/government/statistics/solarphotovoltaics-deployment (Accessed 7 August 2017).

Dwf (2015). Do private wire arrangements work for district energy schemes. [Online] https://www.dwf.law/news-events/legal-updates/2015/09/do-private-wire-arrangementswork-for-district-energy-schemes/ (Accessed 2 December 2016).

EDF (2016a). EDF energy wins contract for 49 MW battery. [Online] http://media.edfenergy.com/r/1148/edf_energy_renewables_wins_contract_for_49_mw_batte ry (Accessed 27 November 2016).

EDF (2016b). EDF renewable energy at a glance. [Online] http://www.edf-re.com/about/edfrenewable-energy-at-a-glance/ (Accessed 27 November 2016). 
Everoze (2016a). Cracking the code: a guide to energy storage revenue streams and how to derisk them.

Everoze (2016b). 3 hard won lessons from the UKs enhanced frequency response tender. [Online] http://everoze.com/3-hard-won-lessons-from-the-uks-enhanced-frequency-responsetender/ (Accessed 27 November 2016).

Hannon, M. J. and Bolton, R. (2015). UK Local Authority engagement with the Energy Service Company (ESCo) model: Key characteristics, benefits, limitations and considerations. Energy Policy, 78: 198-212.

Hart, O. (1996). An economist's perspective on the theory of the firm. In: Buckley, P. J. and Michie J. (eds.) Firms, organisations and contracts. Oxford University Press.

He, X. H., Delarue, E., D'haeseleer, W. and Glachant, J. M. (2011) A novel business model for aggregating the values of electricity storage. Energy Policy, 39(3): 1575-1585.

International Energy Agency (2014). Energy storage: technology roadmap. Paris: IEA.

Kalilpour, R. and Vassallo, A. (2015). Leaving the grid: an ambition or a real choice? Energy Policy, 82: 207-221.

KPMG (2016). [Online] Enhanced frequency response tender results. [Online] https://home.kpmg.com/uk/en/home/insights/2016/09/enhanced-frequency-response-erptender.html (Accessed 27 November 2016).

Magretta, J. (2002). Why business models matter. [Online] Harvard Business Review, 80: 3 8.

McKinsey Global Institute (2013). Disruptive technologies: advance that will transform life business and the global economy.

Moixa (2016). Soon every home will run on batteries. [Online] http://www.moixa.com/ (Accessed 27 November 2016).

MIT (2016), Utility of the Future, MIT energy initiative, December.

Moixa (2017). Smart energy islands project. [Online] http://www.moixa.com/casestudy/smart-energy-islands/ (Accessed 12 May 2017). 
National Infrastructure Commission (2016). Smart Power.

New Power (2016). Battery storage the bid winner in sub second frequency response tender. [Online] http://www.newpower.info/2016/08/battery-storage-the-bid-winner-in-sub-secondfrequency-response-tender/ (Accessed 27 November 2016).

Nillesen, P. and Pollitt, N. (2016). New business models for utilities to meet the challenge of the energy transition. Chapter 15 in FP Sioshansi (ed.), Future of Utilities - Utilities of the Future: How Technological Innovations in Distributed Energy Resources Will Reshape the Electric Power Sector. Academic Press, Incorporated, Amsterdam: 363-382.

North Star Solar (2016). About us. [Online] http://northstarsolar.co.uk/ (Accessed 27 November 2016).

Office for Gas and Electricity Markets (2014). White label providers: call for evidence. [Online] https://www.ofgem.gov.uk/sites/default/files/docs/2014/03/white_label_providers__call_for_evidence_0.pdf (Accessed 2 December 2016).

Office for Gas and Electricity Markets (2015a). Non-traditional business models: supporting transformative change in the energy market. Discussion Paper. London: Office for Gas and Electricity Markets.

Office for Gas and Electricity Markets (2015b). An introduction to Licence Lite. [Online] https://www.ofgem.gov.uk/sites/default/files/docs/2015/04/482_an_introduction_to_licence_1 ite_factsheet_web_0.pdf (Accessed 2 December 2016).

Office for Gas and Electricity Markets (2017). Feed-In-Tariff rates [Online]. https://www.ofgem.gov.uk/environmental-programmes/fit/fit-tariff-rates (Accessed 7 August 2017).

Open Utility (2016). A glimpse into the future of Britain's energy economy [Online] https://www.openutility.com/press/ (Accessed 26 October 2017).

Osterwalder, A. and Pigneur, Y. (2009). Business model generation: a handbook for visionaries, game changers, and challengers. Hoboken, New Jersey: John Wiley and Sons, Inc. 
Poudineh, R. and Jamasb, T. (2014) Distributed generation, storage, demand response, and energy efficiency as alternatives to grid capacity enhancement. Energy Policy, 67: 222-231.

Powervault (2016). Why choose powervault to store your solar energy? [Online] http://www.powervault.co.uk/powervault-to-store-your-solar-energy/ (Accessed 27 November 2016).

Regen SW (2016). Energy storage - towards a commercial model. Exeter: Regen SW.

Renewable Energy Association (2015). Energy storage in the UK: an overview.

Rocky Mountain Institute (2015). The economics of battery storage: how multi-use, consumer-sited batteries deliver the most value to customers and grid. Boulder, Colorado: Rocky Mountain Institute.

Simcock, N. Willis, R. and Capener, P. (2016). Cultures of community energy: international case studies. London: British Academy.

Smart Energy Special Interest Group (2013). The role of community energy systems in the UK resilient energy supply.

Smartest Energy (2016a). Making the commercial case for battery storage.

Smartest Energy (2016b). What's next after enhanced frequency response? [Online] http://www.smartestenergy.com/info-hub/blog/what-s-next-after-enhanced-frequencyresponse/ (Accessed 27 November 2017).

Solar Trade Association (2017). STA secures tax win for solar and batteries for householders. [Online] http://www.solar-trade.org.uk/sta-secures-tax-win-for-solar-and-batteries-forhouseholders/ (Accessed 7 August 2017).

UK Energy Research Centre (2017) A smart, flexible energy system: the UK Energy Research Centre's (UKERC) response to the Ofgem/BEIS call for evidence.

UK Power Network (2013). Smarter network storage - business model consultation.

US Department of Energy (2016). Global energy storage database: projects. [Online] http://www.energystorageexchange.org/ (Accessed 27 November 2016). 
Western Power Distribution (2016). SoLA BRISTOL Project: closedown report.

WSP and Parsons Brinckerhoff (2016). Energy storage: the final piece of the jigsaw? 


\section{Appendix}

Non-traditional business models of energy storage

\begin{tabular}{|c|c|c|c|}
\hline Model & Value proposition & Consumer & Ownership \\
\hline \multicolumn{4}{|c|}{ Baseline Layer } \\
\hline $\begin{array}{l}\text { On-grid } \\
\text { consumers }\end{array}$ & 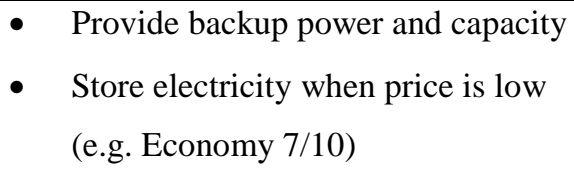 & $\begin{array}{l}\text { - Domestic sector } \\
\text { - Private sector } \\
\text { - Public sector }\end{array}$ & $\begin{array}{l}\text { - Technology bought and } \\
\text { owned by individual } \\
\text { consumers }\end{array}$ \\
\hline $\begin{array}{l}\text { Off-grid } \\
\text { consumers }\end{array}$ & $\begin{array}{l}\text { - Support or create an independent, } \\
\text { e.g., rural or island network } \\
\text { - } \quad \text { Provide backup power } \\
\text { - } \quad \text { Store electricity when price is low } \\
\text { (e.g. Economy } 7 / 10)\end{array}$ & $\begin{array}{ll}\text { - } & \text { Local residents } \\
\text { - } & \text { Local council }\end{array}$ & $\begin{array}{ll}\text { - } & \text { Local residents } \\
\text { - } & \text { Local trusts } \\
\text { - } & \text { Local councils }\end{array}$ \\
\hline
\end{tabular}

Source: Chmiel and Bhattacharyya (2015); WSP and Parsons Brinckerhoff (2016)

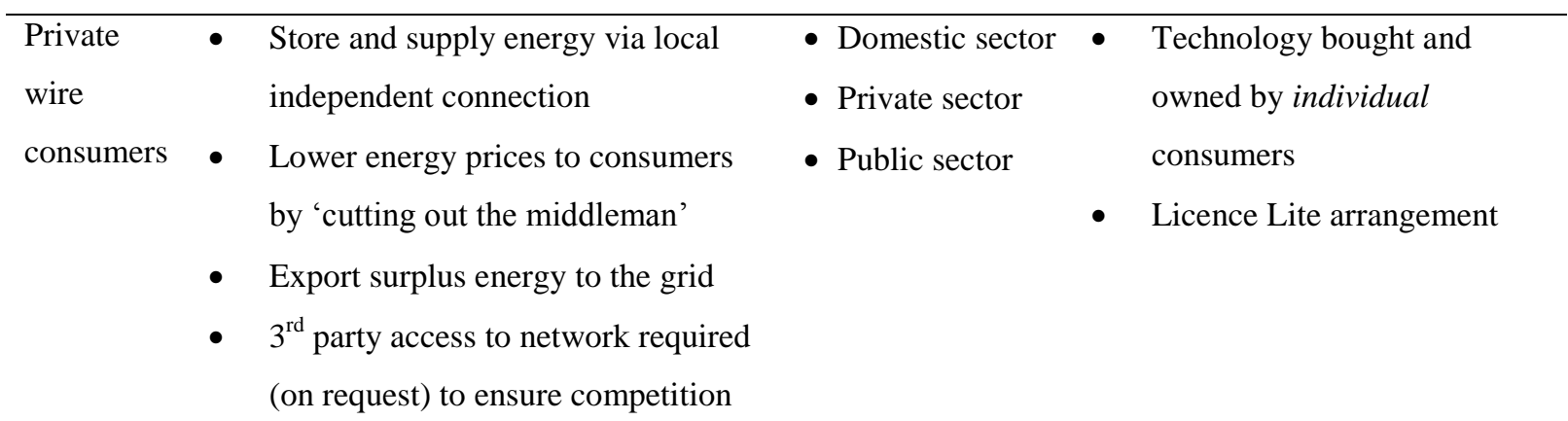

Source: DWF (2015)

\begin{tabular}{|c|c|c|c|}
\hline \multicolumn{4}{|c|}{ Core Layer } \\
\hline Prosumers & 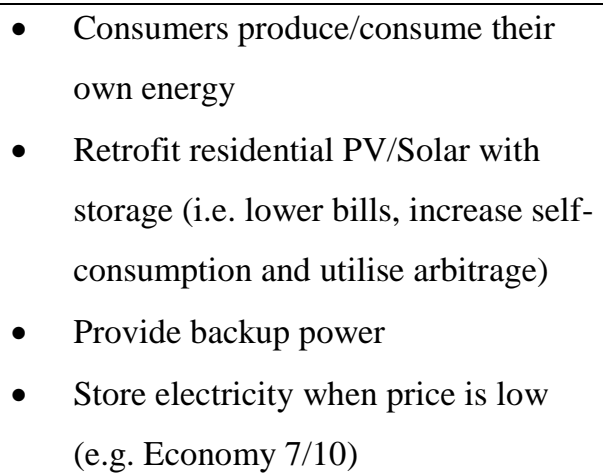 & $\begin{array}{l}\text { - Domestic sector } \\
\text { - Private sector } \\
\text { - Public sector }\end{array}$ & $\begin{array}{l}\text { - Technology bought and } \\
\text { owned by individual } \\
\text { consumers }\end{array}$ \\
\hline Source: Eve & rose (2016a) & & \\
\hline
\end{tabular}




\begin{tabular}{|c|c|c|c|}
\hline \multicolumn{4}{|c|}{ Core Layer Continued } \\
\hline Aggregators & $\begin{array}{l}\text { - } 3^{\text {rd }} \text { party aggregates storage devices } \\
\text { and accesses ancillary (upstream) } \\
\text { services (e.g. frequency response) } \\
\text { - } \quad \text { Revenues shared between } 3^{\text {rd }} \text { party } \\
\text { and storage owners (reflecting costs } \\
\text { and risk) } \\
\text { - } \text { Reduce energy bills, increase self- } \\
\text { consumption } \\
\text { Opportunities: FiT, ToU tariffs, } \\
\text { time shifting and peak reduction }\end{array}$ & $\begin{array}{l}\text { Primary: } \\
\text { - Domestic sector } \\
\text { - Private sector } \\
\text { - Public sector } \\
\text { Ancillary: } \\
\text { - National grid } \\
\text { - Network } \\
\text { - Gerators }\end{array}$ & $\begin{array}{l}\text { - Consumer owns storage } \\
\text { technology } \\
\text { - } 3^{\text {rd }} \text { party intermediary owns } \\
\text { a contracted amount of } \\
\text { energy stored by participants } \\
\text { / or sell energy one day } \\
\text { ahead } \\
\text { PPA }\end{array}$ \\
\hline
\end{tabular}

Source: Delta Energy and Environment (2016); Ofgem (2015a)

\begin{tabular}{|c|c|c|c|}
\hline $\begin{array}{l}\text { Aggregators } \\
+\end{array}$ & $\begin{array}{l}\text { Install solar and storage at zero } \\
\text { upfront or O\&M costs (which are } \\
\text { recovered from energy bill savings) } \\
\text { - } \quad \text { Consumers possibly misses-out on } \\
\text { aggregation/ancillary revenue } \\
\text { - } \quad \text { Reduce energy bills, increase self- } \\
\text { consumption } \\
\text { Opportunities: FiT, ToU tariffs, } \\
\text { time shifting and peak reduction }\end{array}$ & $\begin{array}{l}\text { Primary: } \\
\text { - Domestic sector } \\
\text { - Private sector } \\
\text { - Public sector } \\
\text { Ancillary: } \\
\text { - National grid } \\
\text { - Network } \\
\text { operators } \\
\text { - Generators }\end{array}$ & $\begin{array}{l}\text { - } \quad \text { Consumer owns storage } \\
\text { technology at end of contract } \\
\text { (=payback period) } \\
\text { - } 3^{\text {rd }} \text { party intermediary owns } \\
\text { a contracted amount of } \\
\text { energy stored by participants } \\
\text { / possibly sell one day ahead } \\
\text { PPA }\end{array}$ \\
\hline Sour & $\mathrm{Star} \mathrm{Sc}$ & & \\
\hline $\begin{array}{l}\text { Community } \\
\text { groups }\end{array}$ & 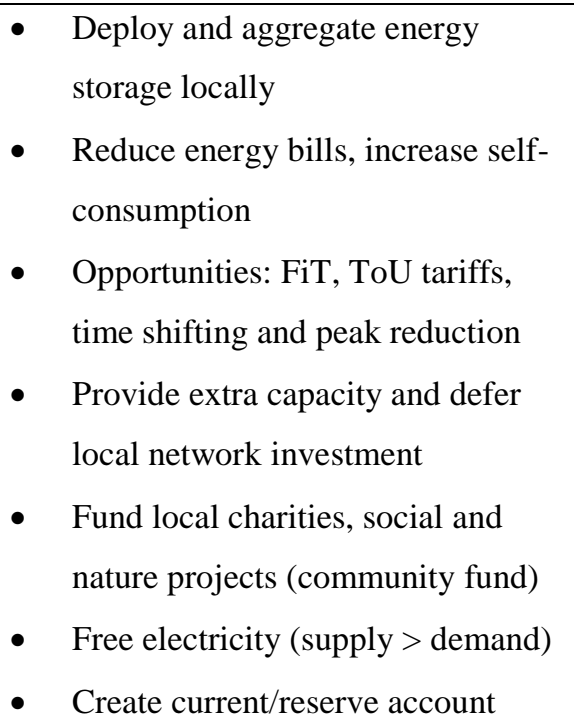 & $\begin{array}{l}\text { Primary: } \\
\text { - Domestic sector } \\
\text { - Private sector } \\
\text { - Public sector } \\
\text { Ancillary: } \\
\text { - National grid } \\
\text { - Network } \\
\text { - operators }\end{array}$ & 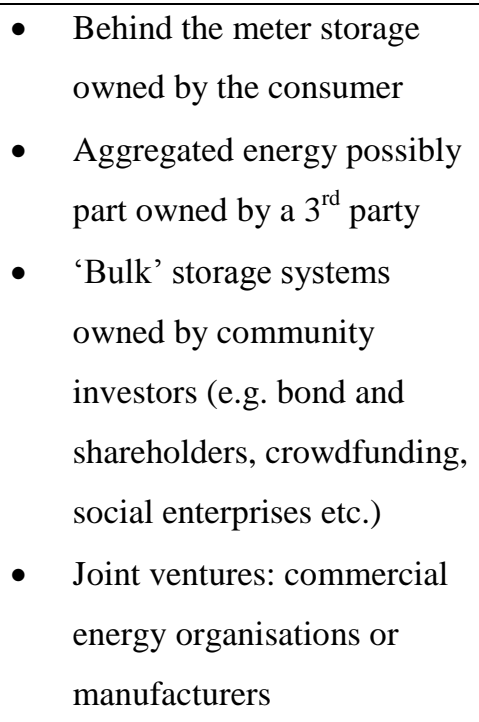 \\
\hline
\end{tabular}

Source: Delta Energy and Environment (2016); Ofgem (2015a); Moixa (2016) 


\section{Core Layer Continued}

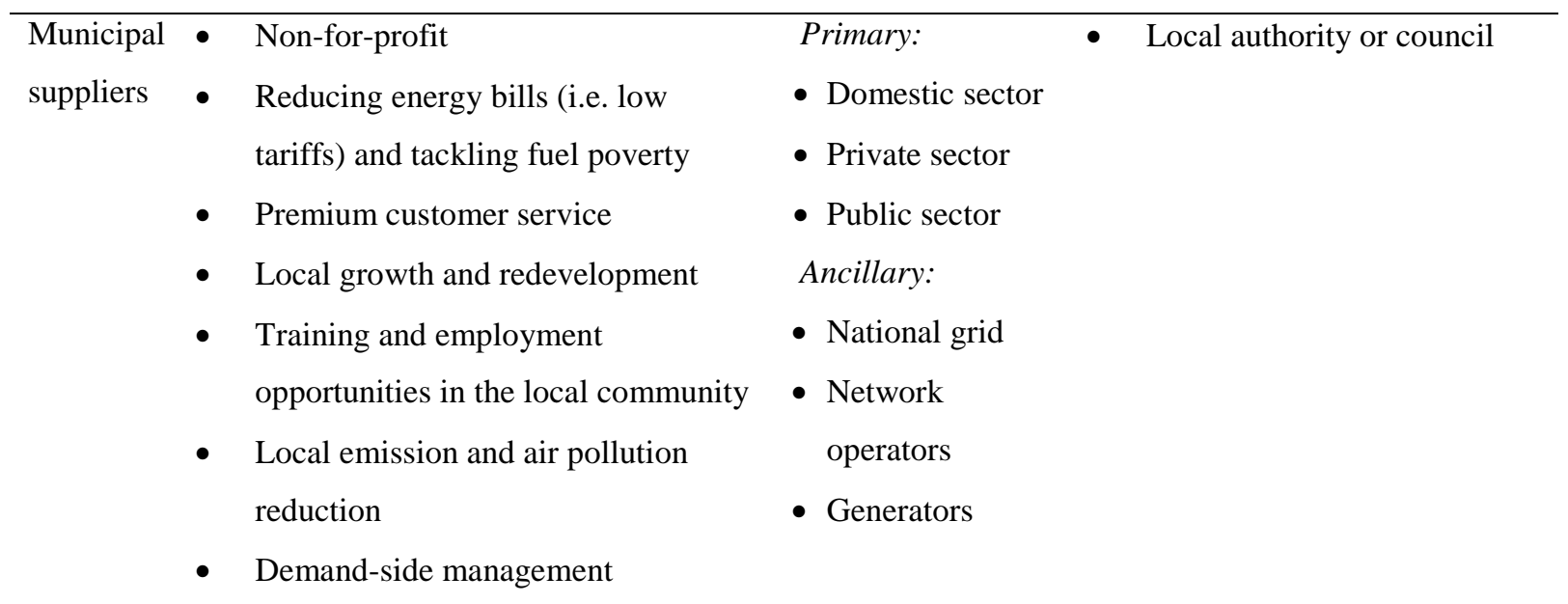

Source: Smartest energy (2016a); Bale and Roelich (2014)

\begin{tabular}{|c|c|c|c|}
\hline $\begin{array}{l}\text { DNO } 3^{\text {rd }} \\
\text { parties }\end{array}$ & $\begin{array}{l}\text { - } 3^{\text {rd }} \text { party owns, manages or provides } \\
\text { ancillary storage services to DNO, as } \\
\text { DNOs restricted to owning small } \\
\text { scale generation (storage is currently } \\
\text { defined as generation) } \\
\text { - Defer network upgrade and } \\
\text { maintenance costs } \\
\text { - Share risk/costs (e.g. joint venture) }\end{array}$ & - DNO & 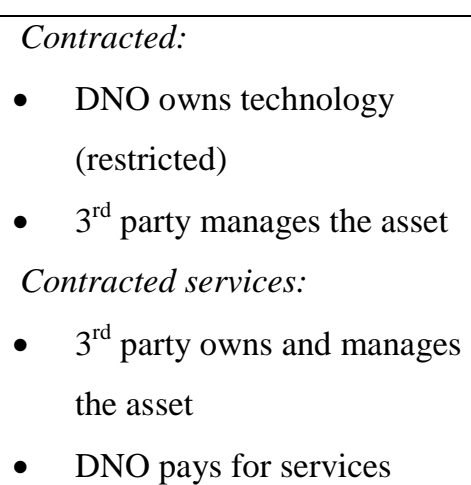 \\
\hline
\end{tabular}

Source: UK Power Network (2013); WSP and Parsons Brinckerhoff (2016)

\begin{tabular}{|c|c|c|c|}
\hline \multicolumn{4}{|c|}{ Service Layer } \\
\hline $\begin{array}{l}\text { Licence } \\
\text { lite } \\
\text { providers }\end{array}$ & $\begin{array}{l}\text { - Small supplier procures and supports } \\
\text { decentralised energy and storage } \\
\text { - Contracted } 3^{\text {rd }} \text { party licence supplier } \\
\text { (TPLS) takes responsibility for } \\
\text { standard licence condition (SLC) } \\
11.2 \text { reducing risk, financial and } \\
\text { technical barriers for suppliers } \\
\text { - Supply local consumers with energy } \\
\text { and provide low energy bills } \\
\text { - Reduce emissions and local air } \\
\text { pollution }\end{array}$ & $\begin{array}{l}\text { - Domestic sector } \\
\text { - Private sector } \\
\text { - Public sector }\end{array}$ & $\begin{array}{l}\text { - Local authority or council } \\
\text { - Local small suppliers, } \\
\text { district energy schemes } \\
\text { (>2.5MW) } \\
\text { Contracted services: } \\
\text { - Third party licence } \\
\text { arrangement with TPLS } \\
\text { Licence Lite supplier } \\
\text { contract local generators and } \\
\text { storage systems }\end{array}$ \\
\hline Irce & VF (2015); Ofgem (2015b) & & \\
\hline
\end{tabular}




\section{Service Layer Continued}

\begin{tabular}{|c|c|c|c|}
\hline $\begin{array}{l}\text { White } \\
\text { label } \\
\text { providers }\end{array}$ & $\begin{array}{l}\text { Parent supplier operates and manages } \\
\text { the supply of energy and customer } \\
\text { service (including billing) } \\
\text { - The white label differentiates itself } \\
\text { from the incumbent suppliers (e.g. } \\
\text { focuses on social enterprises, non- } \\
\text { profit etc.) }\end{array}$ & - Generators & $\begin{array}{l}\text { Contracted services: } \\
\text { - } \quad 3^{\text {rd }} \text { party owns contracted } \\
\text { services paid for by the } \\
\text { generator / incumbent } \\
\text { supplier }\end{array}$ \\
\hline \multicolumn{4}{|c|}{ Source: Ofgem (2014) } \\
\hline $\begin{array}{l}\text { Multiple } \\
\text { service } \\
\text { providers }\end{array}$ & $\begin{array}{l}\text { Provide multiple services: routes to } \\
\text { revenue streams, investors and } \\
\text { developers; contract and other } \\
\text { management services; optimisation } \\
\text { and revenue maximisation services; } \\
\text { project development; finance; } \\
\text { building and installation of energy } \\
\text { storage technology; ICT services, } \\
\text { data storage and data management }\end{array}$ & $\begin{array}{l}\text { - } \begin{array}{l}\text { Storage } \\
\text { owners }\end{array}\end{array}$ & $\begin{array}{l}-3^{\text {rd }} \text { party (ESCOs), local } \\
\text { authority or council owns } \\
\text { contract(s) } \\
\text { - } \quad 3^{\text {rd }} \text { party (ESCOs), local } \\
\text { authority or council does not } \\
\text { own technology or energy } \\
\text { generated }\end{array}$ \\
\hline \multicolumn{4}{|c|}{ Source: Ofgem (2015a); Smartest energy (2016a) } \\
\hline $\begin{array}{l}\text { Peer-to- } \\
\text { Peer } \\
\text { specialists }\end{array}$ & $\begin{array}{l}\text { The creation of a city-wide virtual } \\
\text { platform in which consumers can } \\
\text { produce, store and trade energy }\end{array}$ & $\begin{array}{l}\text { - Domestic sector } \\
\text { - Private sector } \\
\text { - Public sector }\end{array}$ & $\begin{array}{l}\text { - Trading platform owned by } \\
3^{\text {rd }} \text { party } \\
\text { - Storage technology and } \\
\text { energy owned by consumers }\end{array}$ \\
\hline \multicolumn{4}{|c|}{ Source: Ofgem (2015a) } \\
\hline $\begin{array}{l}\text { Software } \\
\text { specialists }\end{array}$ & $\begin{array}{l}\text { Create and deliver innovative } \\
\text { technology solutions and provide } \\
\text { maintenance services to consumers. }\end{array}$ & $\begin{array}{ll} & \text { All business } \\
& \text { models }\end{array}$ & $\begin{array}{l}\text { Developer owns the software } \\
\text { (patent) } \\
\text { - Consumers own purchased } \\
\text { products and upgrades }\end{array}$ \\
\hline & n (2015a); Nillese & & \\
\hline
\end{tabular}

